\title{
Characteristics of a Laboratory Strain of Coleomegilla maculata with a Novel Heritable Wing Spot Pattern Trait
}

\author{
Margaret Louise Allen \\ Biological Control of Pests Research Unit, National Biological Control Laboratory, US Department of Agriculture, \\ Agricultural Research Service, Stoneville, MS, USA \\ Email:meg.allen@ars.usda.gov
}

Received 30 November 2015; accepted 26 January 2016; published 29 January 2016

Copyright (C) 2016 by author and Scientific Research Publishing Inc.

This work is licensed under the Creative Commons Attribution International License (CC BY). http://creativecommons.org/licenses/by/4.0/

c) (i) Open Access

\begin{abstract}
The lady beetle Coleomegilla maculata is a common New World insect that is naturally colored pink to red or orange with black spots on the forewings of the adult stage. Previous laboratory inbreeding resulted in selection for a strain lacking red pigment in the cuticle and eyes. An additional strain selected for a novel spotting pattern is described here. The inheritance of the new trait, "ten spotted" (10sp), was determined by classical crossing experiments. Inheritance of the trait was autosomal and exhibited incomplete dominance. Bionomic strain measurements were compared to the parental strains and were similar overall. Two expressed sequences from $C$. maculata that may be related to the new phenotype were compared to model insect genes encoding a melanin biosynthesis enzyme and a patterning transcription factor.
\end{abstract}

\section{Keywords}

\section{Coccinellidae, Mutant Phenotype, Melanin, Ebony, Wing Pattern}

\section{Introduction}

Many beetles in the family Coccinellidae are identified by the number and pattern of spots appearing on the forewings, or elytra. Both the common and scientific names of many species describe the numbers of spots; for example, Adalia bipunctata (Linneaus) is commonly called the two-spotted lady beetle, Coccinella septempunctata Linnaeus is the seven-spotted lady beetle, and Coccinella novemnotata Herbst is the nine-spotted lady beetle. The species Coleomegilla maculata (DeGeer) (Coleoptera: Coccinellidae) is commonly called the pink lady beetle or the twelve-spotted lady beetle. It is a beneficial omnivore found in US agroecosystems and occurs 
throughout much of the North and South American continents. The name "twelve-spotted lady beetle" describes the typical spot pattern on C. maculata: dark spots on a lighter background that is pink to red or orange. While numerous color and pattern variations in other species of coccinellids have been described, and the inheritance of those patterns have been analyzed [1], C. maculata is not a species that exhibits dramatic polymorphism in wild populations, and therefore it has not been used as a model for phenotype inheritance.

To facilitate genetics and biological control research, colonies of $C$. maculata were kept in continuous culture and inbred for over 64 generations since 2009. One result of inbreeding was the discovery and selection of novel phenotypes unique to laboratory strains. A stable homozygous strain of pale eyed beetles with pale yellow coloration in the cuticle, ye, was described earlier [2]. After further laboratory inbreeding, an additional phenotypic trait was identified and selected and was described here. This trait involved the pattern of spots on the elytra of the adult beetles. The pattern was an expanded dark region of the two anterior spots on each elytron such that the spots merged. This trait was labeled "ten spotted" and the strain abbreviated 10sp. The pattern was observed in both the wild type strain and in the ye strain. Phenotypically distinct individuals exhibiting both the ye and 10sp traits combined were selected, bred to stability, and crossed back to the parental twelve spotted phenotype to determine the heritability of the trait. To evaluate the effects of the trait on overall fitness of the insects, selected biometric measurements of the ye/10sp strain were compared to those of the wild type and the ye laboratory strains. Two sequences that were predicted as potential candidate genes contributing to the phenotype were identified, and compared with genes from model insects.

\section{Methods}

The $y e / 10 s p$ strain was analyzed using classical Mendelian breeding and documented by digital image collection. Insects were maintained as previously described [2] [3]. Individual insects were isolated for reciprocal straincrosses, and putative heterozygous first generation offspring (F1) crosses were pooled. Observed phenotype data were collected and entered into a spreadsheet, and phenotypic ratios were compared to expected Mendelian ratios for a single locus incomplete dominant allele using chi-squared distribution test (Excel ${ }^{\circledR}$, Microsoft Corporation, Redmond, WA, USA). The expected phenotype of all offspring from a homozygous 10sp parent mated to an individual with wild type twelve spotted pattern was all 10sp, but with a heterozygous moderate expression pattern. Offspring from heterozygous parents were expected to result in $75 \% 10 s p$ and $25 \%$ twelve spotted wild type phenotypes; offspring from a heterozygous parent mated to a wild type individual were expected to result in half $10 s p$ and half wild type phenotypes. Images were collected using a Nikon digital camera, DMX 1200, with factory supplied ACT-1 software. The camera was mounted on a Nikon Stereomicroscope SMZ1500 (Nikon Corporation, Tokyo, Japan) with aperture fully closed to provide maximum depth of field. Objective lens was WD54 1x, oculars C-W10xA/22. Zoom was set at $0.75,1$, and 2 for various images. Shutter speeds were $1 / 50$ to $1 / 75$ sec. A Nikon NI-150 high intensity double gooseneck illuminator set at $75 \%$ or higher intensity illuminated the subjects from two opposing sides.

To estimate strain fecundity, the number of eggs in egg masses were counted as harvested from stable strain colony cages. A grouping of more than four eggs clustered together was considered a mass. To estimate fecundity and fertility on a finer scale, mature and apparently gravid individual females were isolated from each strain and eggs were collected and counted on a daily basis over ten consecutive days. Eggs were observed daily and the number of hatched neonates was counted. Pupae were weighed individually using a Sartorius CP2P-F analytical balance. Data were analyzed by one way analysis of variance using SigmaPlot, version 12software (SSI, San Jose, CA USA).

As research on coccinellids advances, high-throughput sequencing is expected to play a greater role in both gene expression study and defining molecular markers [4]. A high-throughput sequencing project was undertaken utilizing total RNA extracted from highly inbred (six isofemale selection steps) specimens of C. maculata, resulting in two adult transcriptomes that assembled into over 33,000 sequences each [5]. Two predicted complete protein coding sequences identified from the C. maculata transcriptomes [5] were compared to sequences in NCBI GenBank using BLAST alignment [6]. Characterized protein sequences from model insects were aligned with the predicted C. maculata sequences using DNASTARLasergene 8 MegAlign software (Madison, WI USA).

\section{Results}

Inheritance of the 10sp trait is autosomal and exhibits incomplete dominance. Reciprocal crosses of insects with 
the trait and wild type or ye insects having the characteristic twelve spot phenotype produced offspring with expansion and merging of the anterior spots as heterozygotes, following expected Mendelian inheritance ratios (Table 1). All crosses resulted in ratios of offspring that did not differ from the expected ratios for an incomplete dominant autosomal allele $(p>0.05)$. The offspring of heterozygotes, when mated, produced offspring with a range of phenotypes including the normal spotting pattern, with twelve spots, and enlarged spots that were partially merged, and fully merged spots. Strain types are shown in Figure 1, with the homozygous characteristic pattern of the 10sp strain shown in Figure 1(B), and an example of a heterozygous ten spotted pattern shown in Figure 1(C). The differences between the homozygous and heterozygous patterns were subtle and for counts of the inherited trait, any variation of the trait was counted as ten spotted. Digital images of individual insects in homozygous and heterozygous form were compared by measuring the smallest region of the constriction between merged spots, the "waist", and the widest region of the anterior spot, and using the measurements to estimate a ratio (Figure 2). The spot ratio of homozygous beetles was $0.886 \pm 0.0347(\mathrm{n}=13)$ while the ratio of heterozygous beetles was $0.542 \pm 0.0819(\mathrm{n}=8)$. These ratios were significantly different (student $\mathrm{t}$-test, $p<$ 0.001).

As represented in Figure 3, the strain ye/10sp was similar in fecundity and fertility to the laboratory wild type strain and the ye strain. Egg masses collected from the ovipositing colony cages did not differ significantly in size ( $F=0.613, d f=2, p=0.543$ ). Because the egg masses collected from the colony cages might represent interrupted oviposition events, a second fecundity estimate was measured. Fecundity was measured by the number of eggs produced in ten days by individual gravid females from each of three strains. Individual gravid females produced quantities of eggs over a ten day period that were not significantly different $(F=3.052, d f=2, p=$ 0.067). However, wild type fertile egg masses had a higher hatch rate compared with the ye strain $(F=3.882$, $d f=2, p=0.046)$, and the hatch rate was significant among the treatment groups $(p=0.039)$. However, the

\section{Table 1. Segregation of adult pattern in the progeny of crosses between 10sp and 12 spotted parents.}

\begin{tabular}{|c|c|c|c|c|c|}
\hline \multicolumn{6}{|c|}{ Adult phenotype } \\
\hline Cross (female $\times$ male) & 10 spot & 12 spot & Total & Expected $^{*}$ & $c^{2} p$ value \\
\hline Strong $10 s p \times 12$ spot (Experiment 1 ) & 74 & - & 74 & 74:0 & $\mathrm{n} / \mathrm{a}$ \\
\hline Strong 10sp $\times 12$ spot (Experiment 1$)$ & 33 & - & 33 & 33:0 & $\mathrm{n} / \mathrm{a}$ \\
\hline Strong 10sp × 12 spot (Experiment 1 ) & 63 & - & 63 & 63:0 & $\mathrm{n} / \mathrm{a}$ \\
\hline${ }^{*}$ For dominant phenotype, $100 \% 10$ sp is expected & & & & & 1 \\
\hline 12 spot $\times$ Strong 10sp (Experiment 1$)$ & 77 & - & 77 & 77:0 & $\mathrm{n} / \mathrm{a}$ \\
\hline 12 spot $\times$ Strong 10sp (Experiment 2) & 46 & - & 46 & 46:0 & $\mathrm{n} / \mathrm{a}$ \\
\hline 12 spot $\times$ Strong 10sp (Experiment 3) & 54 & - & 54 & 54:0 & $\mathrm{n} / \mathrm{a}$ \\
\hline${ }^{*}$ For dominant phenotype, $100 \% 10$ sp is expected & & & & & 1 \\
\hline Moderate 10sp group (Experiment 1) & 31 & 18 & 49 & $36.75: 12.25$ & 0.05783 \\
\hline Moderate 10sp group (Experiment 2) & 42 & 11 & 53 & 39.75:13.25 & 0.47538 \\
\hline Moderate 10sp group (Experiment 3) & 35 & 7 & 42 & $31.5: 10.5$ & 0.21232 \\
\hline${ }^{*}$ For heterozygous cross, a 3:1 ratio is expected & & & & & 0.05891 \\
\hline Moderate $10 s p \times 12$ spot (Experiment 1) & 34 & 33 & 67 & 33.5:33.5 & 0.78574 \\
\hline Moderate 10sp × 12 spot (Experiment 2) & 19 & 19 & 38 & $19: 19$ & 0.48519 \\
\hline Moderate $10 s p \times 12$ spot (Experiment 3) & 28 & 27 & 55 & 27.5:27.5 & 0.68542 \\
\hline *For heterozygous to wild type cross, a 1:1 ratio is expected & & & & & 0.98004 \\
\hline 12 spot $\times$ Moderate $10 s p$ (Experiment 1 ) & 39 & 38 & 77 & 38.5:38.5 & 0.84727 \\
\hline 12 spot $\times$ Moderate 10sp (Experiment 2) & 29 & 27 & 56 & $28: 28$ & 0.73160 \\
\hline 12 spot $\times$ Moderate 10sp (Experiment 3) & 27 & 30 & 57 & 28.5:28.5 & 0.66618 \\
\hline${ }^{*}$ For heterozygous to wild type cross, a 1:1 ratio is expected & & & & & 0.99578 \\
\hline
\end{tabular}




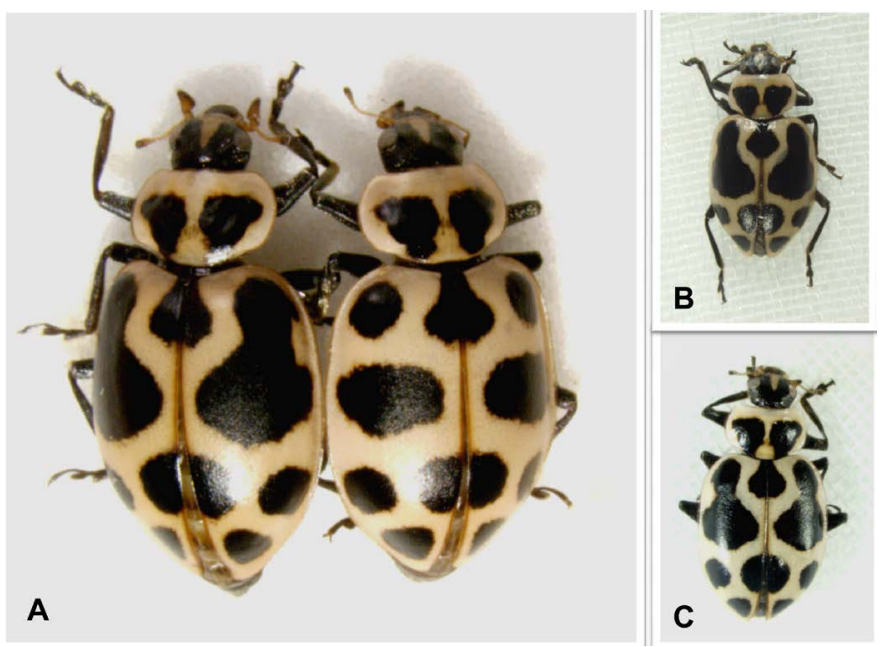

Figure 1. The ten spotted (10sp) phenotype of Coleomegilla maculata. (A) Two specimens of the yellow eyes and elytra (ye) phenotype exhibiting the typical twelve spotted pattern (right) and the $10 s p$ form (left) with merged spots on elytra. (B) A specimen exhibiting the homozygous form of the trait; the merged spots have very little constriction between them. (C) A specimen exhibiting the heterozygous trait form. The dark area between the spots is narrowed.

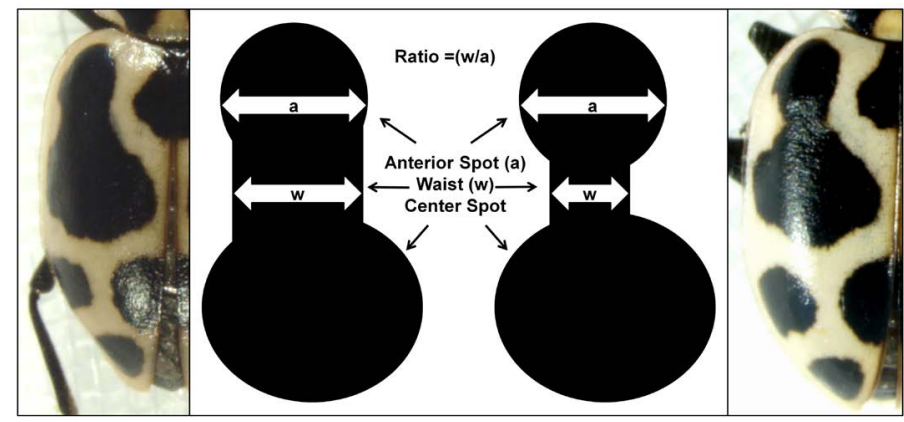

Figure 2. Diagram of measurement of the spot shape of individuals to identify incomplete dominance characteristics, with images of insect elytra flanking diagrammatic representations. Left: strong homozygous phenotype, with a wide waist region of melanization. Right, moderate heterozygous phenotype, with a narrow waist region of melanization.

difference between the ye/10sp and ye rate was not statistically significant. The mass of pupae from the three strains were compared and while the mean mass of the individuals from the ye strain were found to be significantly smaller than those of the wild type strain $(F=10.172, d f=2, p<0.001)$, the difference was small $(<10 \%)$ and not visually obvious.

Sequences involved in melanin biosynthesis (predicted $\mathrm{N}-\beta$ alanyldopamine synthase, ebony) and patterning (predicted transcription factor bric a brac) were identified from C. maculata transcriptomes [5]. Predicted translations of the sequences were very similar to those from the red flour beetle, Tribolium castaneum, and somewhat similar to genes from the fly Drosophila melanogaster, both genetically robust model organisms. Table 2 summarizes the similarities by alignment of the $C$. maculata sequences to genetics model insects. Translated sequences and ClustalW alignments are included as Supplementary Figures S1-S4.

\section{Discussion}

The dark colors of insects are often based on pigments in the cuticle. One of the best known dark pigment 


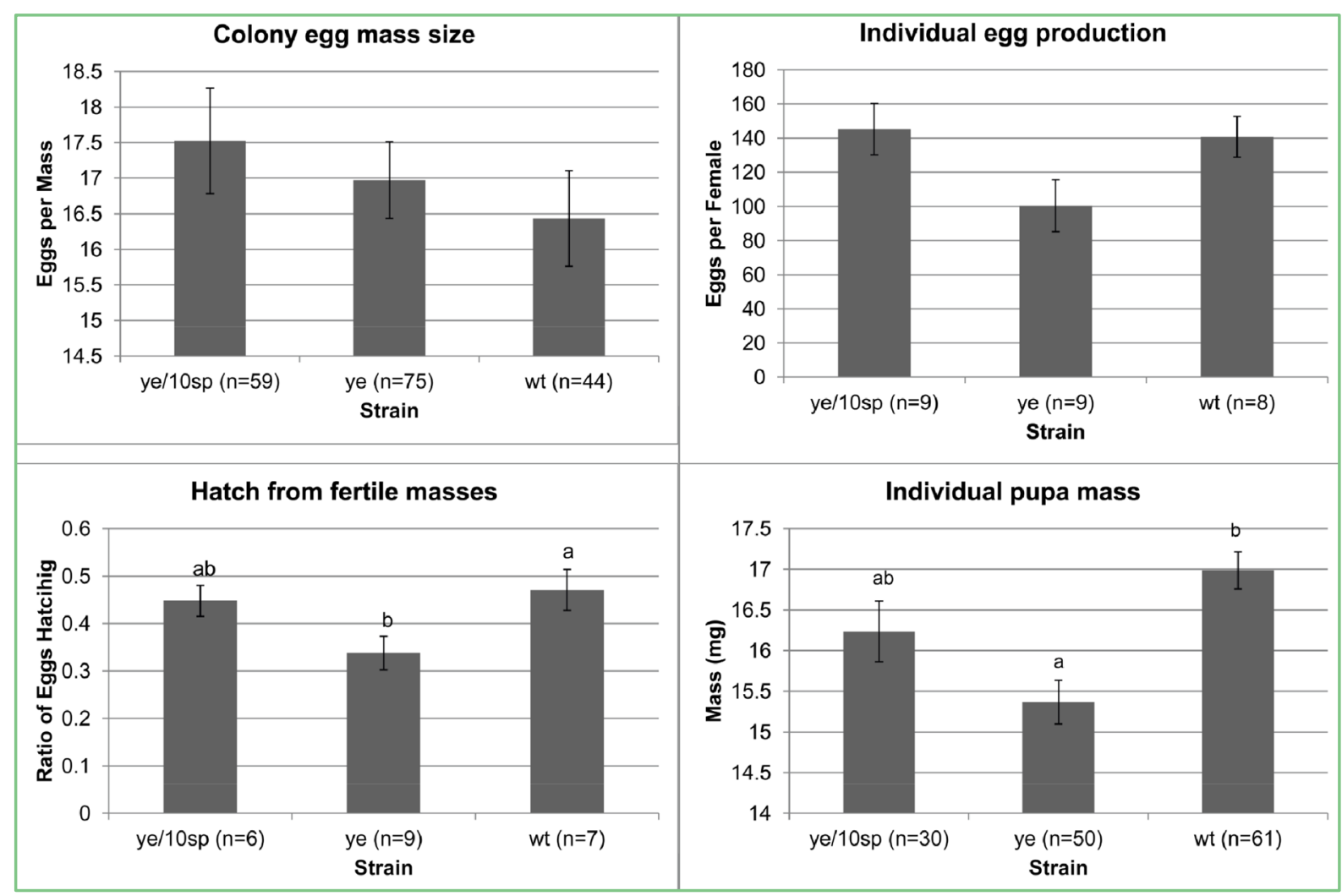

Figure 3. Bionomic measurements of colony strain fitness. Columns depict means with \pm standard error bars. Means labeled with the same letter, or unlabeled columns are not significantly different. Upper left: mean number of eggs per egg mass collected from colonies of a stable homozygous strain of 10 spotted yellow phenotype of Coleomegilla maculata (ye/10sp), a stable homozygous strain of twelve (wild type) spotted yellow phenotype of C. maculata (ye), and a wild type strain (pink with twelve spots) of $C$. maculata (wt). Upper right, mean number of eggs per individual isolated gravid female from a stable homozygous strain of 10 spotted yellow phenotype of $C$. maculata (ye/10sp), a stable homozygous strain of twelve (wild type) spotted yellow phenotype of $C$. maculata (ye), and a wild type strain (pink with twelve spots) of C. maculata (wt). Lower left: mean ratio of hatched eggs to unhatched eggs from masses collected from the three strains: ye/10sp, ye, and wt. Lower right: mean mass of individual pupae (mg) collected from the three strains: ye/10sp, ye, and $w t$.

compounds is melanin, a derivative of the amino acid tyrosine. Melanization in insects is influenced by multiple genes at multiple loci. In Drosophila melanogaster pigment metabolism involves tyrosine hydroxylase, encoded by the gene pale; phenol oxidases and dopa decarboxylase; genes in the Yellow family; the genes black and tan; and N- $\beta$ alanyldopamine synthase, encoded by the gene ebony. In Bicyclus anynana butterflies, different mutations implicating an entirely different enzyme, cysteine sulfinic acid decarboxylase, produce melanic mutants in the larva and adult forms of the insect [7]. The gene ebony has been described in the beetle Tribolium castaneum, and when it is disrupted the resulting phenotype is uniformly dark [8]. Melanic forms of insects, or "dark morphs” may be adapted to resist diseases. For example, a dark form of the wax moth, Galleria mellonella, had a thicker cuticle and was resistant to infection by the entomopathogen Beauveria bassiana, a fungus used commercially for biological control of insect pests [9]. Melanin in insects is also associated with temperature modulation, as demonstrated in the lady beetle Adalia bipunctata. Forms with dark elytra may be better adapted for climate tolerance, particularly in cold conditions, and an associated increase in activity may influences mate choice in some populations [10]. Recent research on the model organism Drosophila melanogaster indicates that dark pigmentation patterning is associated with resistance to ultraviolet radiation exposure, and melanic forms are most closely correlated with high levels of exposure [11]. Toxic defensive compounds and elytra coloration are correlated in Harmonia axiridis [16] and Coccinella septempunctata [17]; whether this is also true for C. maculata is a topic for further research. Both the ye and ye/10sp insects produce reflex hemolymph leakage accompanied by a distinctively unpleasant odor when disturbed (empirical observation), but variation between the 
phenotypic strains has not yet been examined or analyzed.

Patterning in insects may be regulated by transcription factors such as optomotor-blind (omb) or bric a brac (bab) [11]. Color patterns in wings of butterflies are complex, and may be the product of the co-option of developmental pathways, as exemplified by the eye development gene optix which is correlated with wing patterns of Heliconius butterflies [12]. The genes involved in color patterning in beetles have not yet been discovered.

The ladybird beetle $C$. maculata has appealing characteristics for use as a genetic model organism. It is relatively easy to find and maintain in culture, it is visually appealing and unthreatening, and has a relatively rapid reproductive rate. For molecular genetics, it has a small genome, and a pair of transcriptomes of the adult life stage have been sequenced [5]. The species exhibits high genetic polymorphism across its wide geographic distribution [13], and laboratory cultures kept for gene sequencing are more suitable for sample submission when inbred through multiple isofemale selections to increase homozygosity. Naturally occurring mutant strains of other insect species, and of course in domesticated vertebrates, have proven extremely valuable in genetic discovery. The ye and 10sp strains of $C$. maculata do not appear to arise in natural populations, but arose spontaneously during laboratory inbreeding. Recently, a visible pigmentation marker was constructed based on the ebony gene from the silk moth Bombyx mori for use in insect transgenesis [14]. The gene sequences presented herein could be used for similar biotechnology applications research. Coloration in lady beetles is indicative of a wide range physiological and ecological traits of interest. The combination of distinctive phenotypic laboratory strains and increasing genetic sequence availability provide valuable scientific resources for studying complex and fascinating interactive relationships of organisms with the environment, with each other, and in trophic relationships with other organisms.

Comparison of two sequences that are similar to the genes ebony and bric-a-brac from the C. maculata transcriptomes (Supplementary Figures S1-S4) with sequences from the model insects D. melanogaster, B. mori, and T. castaneum (Table 2) indicate that similar genes involved in melanization and patterning are present in $C$.

Table 2. Comparisons of predicted ebony and bric-a-brac sequences from transcriptomes to model insects in GenBank.

\begin{tabular}{|c|c|c|c|c|c|c|c|}
\hline \multicolumn{3}{|c|}{ A. Comparable to Coleomegilla maculata predicted ebony } & \multicolumn{5}{|c|}{ Similarity Scores } \\
\hline Nucleotide sequence & Length & Species & Bit score & Expect & Identities & $\%$ identities & Gaps \\
\hline Predicted: XM_008199683.1 ebony & 2758 & Tribolium castaneum & 360 & $4.00 \mathrm{E}-98$ & $1312 / 2036$ & $64 \%$ & $22 / 2038$ \\
\hline NM_079707.4 ebony & 3142 & Drosophila melanogaster & $\mathrm{n} / \mathrm{a}$ & $\mathrm{n} / \mathrm{a}$ & none & $\mathrm{n} / \mathrm{a}$ & $\mathrm{n} / \mathrm{a}$ \\
\hline \multirow[t]{2}{*}{ NM_001145321.1 ebony } & 3556 & Bombyx mori & 68 & $3.00 \mathrm{E}-10$ & $83 / 113$ & $73 \%$ & $3 / 113$ \\
\hline & & & \multicolumn{5}{|c|}{ Similarity Scores } \\
\hline Translated amino acid sequence & Length & Species & Bit score & Expect & Identities & $\%$ identities & Gaps \\
\hline Predicted: XP_008197905.1 a-ae 19 & 860 & Tribolium castaneum & 1145 & $0.00 \mathrm{E}+00$ & $541 / 856$ & $63 \%$ & $4 / 856$ \\
\hline NP_524431.2 ebony & 879 & Drosophila melanogaster & 896 & 0 & $452 / 881$ & $51 \%$ & 29/881 \\
\hline NP_001138793.1 ebony & 691 & Bombyx mori & 650 & $0.00 \mathrm{E}+00$ & $352 / 694$ & $51 \%$ & $20 / 694$ \\
\hline \multicolumn{3}{|c|}{ B. Comparable to Coleomegilla maculata predicted bric-a-brac } & \multicolumn{5}{|c|}{ Similarity Scores } \\
\hline Nucleotide sequence & Length & Species & Bit score & Expect & Identities & $\%$ identities & Gaps \\
\hline Predicted: XM_008200884.1 bric-a-brac & 1352 & Tribolium castaneum & 457 & $1.00 \mathrm{E}-76$ & $243 / 304$ & $80 \%$ & $0 / 304$ \\
\hline NM_163881.2 mdg4 & 1839 & Drosophila melanogaster & 44.6 & 0.006 & $71 / 102$ & $70 \%$ & $0 / 102$ \\
\hline \multirow[t]{2}{*}{ NM_001112758.1 mdg4 } & 1331 & Bombyx mori & $\mathrm{n} / \mathrm{a}$ & $\mathrm{n} / \mathrm{a}$ & none & $\mathrm{n} / \mathrm{a}$ & $\mathrm{n} / \mathrm{a}$ \\
\hline & & & \multicolumn{5}{|c|}{ Similarity Scores } \\
\hline Translated amino acid sequence & Length & Species & Bit score & Expect & Identities & $\%$ identities & Gaps \\
\hline Predicted: XP_008199106.1 & 350 & Tribolium castaneum & 434 & $8.00 \mathrm{E}-151$ & 230/387 & $59 \%$ & $51 / 387$ \\
\hline NP_732741.1 CG34376 & 681 & Drosophila melanogaster & 158 & $2.00 \mathrm{E}-42$ & $66 / 114$ & $58 \%$ & $0 / 114$ \\
\hline NP_001106229.1 mdg4 & 344 & Bombyx mori & 173 & $4.00 \mathrm{E}-50$ & $127 / 369$ & $34 \%$ & $55 / 369$ \\
\hline
\end{tabular}


maculata. While these particular genes may not play a role in the phenotypes described here, they provide an initiation point for further studies on pigmentation biochemistry and pattern formation in a novel and important beneficial lady beetle. Predictably, the $C$. maculata sequences are more similar to $T$. castaneum sequences than to those of D. melanogaster or B. mori, because the genes of two beetles, albeit distantly related, should logically be more similar to each other than to those from other insect orders, either Diptera or Lepidoptera (respectively). As more genes from non-model organisms are annotated and curated, the conservation and divergence of gene evolution and function will be better understood.

The cost of producing genetic strains is inbreeding depression. The fitness assessments presented here, indicating relatively robust fecundity, fertility, and size, bode well for continuing availability of the strains described here, and other strains. Laboratory inbreeding of biological control agents may change predation characteristics [15], therefore it is important to maintain and improve awareness and understanding of those traits that could lead to changes in the effectiveness of beneficial insects.

Additional studies of coccinellid pigments will require chemical or physical extraction and isolation methods and molecular biological methods such as gene disruption or over expression.

Further studies of C. maculata and related coccinellids and the genetic and biochemical processes responsible for elytra coloration will be facilitated by this unique strain of beetles. Molecular genetic markers will facilitate mark and recapture studies to evaluate immigration and emigration to and from natural and managed ecosystems [4], and even from plant type or species may be possible. This strain is stable in the homozygous form. The strain will be useful for molecular genetic and biochemical studies of insect pigments, immunity, and evolution of gene regulatory networks.

\section{Acknowledgements}

An earlier version of this manuscript was reviewed by Jian Chen and Jonathan G. Lundgren, and anonymous reviewers. The comments and suggestions provided helpful improvement. The author thanks Jeff Gore and Brenda Yant for sharing field collected wild insects to found the original C. maculata colony from Stoneville, MS. The author thanks Mary Elizabeth Huddleston, Joseph Grey Ballenger, and Morgan Holmes for technical support and assistance with insect maintenance. The United States Government has the right to retain a non-exclusive, royalty-free license in and to any copyright of this article. This article reports the results of research only. Mention of a commercial or proprietary product does not constitute an endorsement of the product by the United States Department of Agriculture. USDA is an equal opportunity provider and employer.

\section{Competing Interests}

The author claims no competing interests.

\section{Authors' Contributions}

Margaret L. Allen designed and analyzed all experiments and data.

\section{References}

[1] Sloggett, J.J. and Honek, A. (2012) Genetic Studies. In: Hodek, I., Emden, H.F.V. and Honek, A., Eds., Ecology and Behaviour of the Ladybird Beetles (Coccinellidae), Wiley-Blackwell, Oxford. http://dx.doi.org/10.1002/9781118223208.ch2

[2] Allen, M.L. and Ballenger, J.G. (2014) Genetics and Characteristics of a Pigmentation Defective Laboratory Strain of the Lady Beetle, Coleomegilla maculata. Advances in Entomology, 2, 161-166. http://dx.doi.org/10.4236/ae.2014.24024

[3] Allen, M.L. and Riddick, E.W. (2012) A System for Harvesting Eggs of the Pink-Spotted Lady Beetle. Psyche, 2012, 1-6.

[4] Van Emden, H.F. and Hodek, I. (2012) Recent Progress and Possible Future Trends in the Study of Coccinellidae. In: Hodek, I., Emden, H.F.V. and Honek, A., Eds., Ecology and Behaviour of the Ladybird Beetles (Coccinellidae), Wiley-Blackwell, Oxford, 520-525.

[5] Allen, M.L. (2015) Characterization of Adult Transcriptomes from the Omnivorous Lady Beetle Coleomegilla maculata Fed Pollen or Insect Egg Diet. Journal of Genomics, 3, 20-28. http://dx.doi.org/10.7150/jgen.10385 
[6] Altschul, S.F., Madden, T.L., Schaffer, A.A., Zhang, J., Zhang, Z., Miller, W. and Lipman, D.J. (1997) Gapped BLAST and PSI-BLAST: A New Generation of Protein Database Search Programs. Nucleic Acids Research, 25, 33893402. http://dx.doi.org/10.1093/nar/25.17.3389

[7] Wittkopp, P.J. and Beldade, P. (2009) Development and Evolution of Insect Pigmentation: Genetic Mechanisms and the Potential Consequences of Pleiotropy. Seminars in Cell \& Developmental Biology, 20, 65-71. http://dx.doi.org/10.1016/j.semcdb.2008.10.002

[8] Arakane, Y., Lomakin, J., Beeman, R.W., Muthukrishnan, S., Gehrke, S.H., Kanost, M.R. and Kramer, K.J. (2009) Molecular and Functional Analyses of Amino Acid Decarboxylases Involved in Cuticle Tanning in Tribolium castaneum. Journal of Biological Chemistry, 284, 16584-16594. http://dx.doi.org/10.1074/jbc.M901629200

[9] Dubovskiy, I.M., Whitten, M.M., Kryukov, V.Y., Yaroslavtseva, O.N., Grizanova, E.V., Greig, C., Mukherjee, K., Vilcinskas, A., Mitkovets, P.V., Glupov, V.V. and Butt, T.M. (2013) More than a Colour Change: Insect Melanism, Disease Resistance and Fecundity. Proceedings of the Royal Society Biological Sciences, 280, Article ID: 20130584. http://dx.doi.org/10.1098/rspb.2013.0584

[10] Jong, P., Gussekloo, S. and Brakefield, P. (1996) Differences in Thermal Balance, Body Temperature and Activity between Non-Melanic and Melanic Two-Spot Ladybird Beetles (Adalia bipunctata) under Controlled Conditions. Journal of Experimental Biology, 199, 2655-2666.

[11] Wittkopp, P.J., Carroll, S.B. and Kopp, A. (2003) Evolution in Black and White: Genetic Control of Pigment Patterns in Drosophila. Trends in Genetics, 19, 495-504. http://dx.doi.org/10.1016/S0168-9525(03)00194-X

[12] Kronforst, M.R., Barsh, G.S., Kopp, A., Mallet, J., Monteiro, A., Mullen, S.P., Protas, M., Rosenblum, E.B., Schneider, C.J. and Hoekstra, H.E. (2012) Unraveling the Thread of Nature’s Tapestry: The Genetics of Diversity and Convergence in Animal Pigmentation. Pigment Cell \& Melanoma Research, 25, 411-433. http://dx.doi.org/10.1111/j.1755-148X.2012.01014.x

[13] Steiner, W.W.M. and Grasela, J.J. (1993) Population Genetics and Gene Variation in the Predator, Coleomegilla maculata (De Geer) (Coleoptera: Coccinellidae). Annals of the Entomological Society of America, 86, 309-321. http://dx.doi.org/10.1093/aesa/86.3.309

[14] Osanai-Futahashi, M., Ohde, T., Hirata, J., Uchino, K., Futahashi, R., Tamura, T., Niimi, T. and Sezutsu, H. (2012) A Visible Dominant Marker for Insect Transgenesis. Nature Communications, 3, 1295. http://dx.doi.org/10.1038/ncomms2312

[15] Obrycki, J.J. and Kring, T.J. (1998) Predaceous Coccinellidae in Biological Control. Annual Reviews of Entomology, 43, 295-321. http://dx.doi.org/10.1146/annurev.ento.43.1.295

[16] Bezzerides, A.L., McGraw, K.J., Parker, R.S. and Husseini, J. (2007) Elytra Color as a Signal of Chemical Defense in the Asian Ladybird Beetle Harmonia axyridis. Behavioral Ecology and Sociobiology, 61, 1401-1408. http://dx.doi.org/10.1007/s00265-007-0371-9

[17] Blount, J.D., Rowland, H.M., Drijfhout, F.P., Endler, J.A., Inger, R., Sloggett, J.J., Hurst, G.D.D., Hodgson, D.J. and Speed, M.P. (2012) How the Ladybird Got Its Spots: Effects of Resource Limitation on the Honesty of Aposematic Signals. Functional Ecology, 26, 334-342. http://dx.doi.org/10.1111/j.1365-2435.2012.01961.x

\section{List of Abbreviations Used}

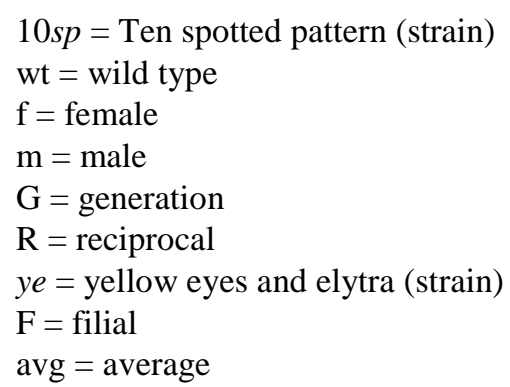




\section{Supplementary}

ggtgaatgtgtcacttcttgaagaacggttcgactggtggattaaatcaaccgaa ttcataccaacgaag ATG GGA TCT CTT CCG CAA TTT TCT ATT TTG

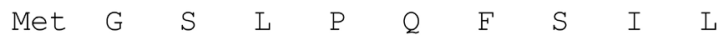

AAA GGG CCG ACC CGA AGA TTC AAC CCT GAA TAT ATA AAT GAT $\begin{array}{llllllllllllll}\mathrm{K} & \mathrm{G} & \mathrm{P} & \mathrm{T} & \mathrm{R} & \mathrm{R} & \mathrm{F} & \mathrm{N} & \mathrm{P} & \mathrm{E} & \mathrm{Y} & \mathrm{I} & \mathrm{N} & \mathrm{D}\end{array}$ GTC ATT GAA TCT ACT CTA TCA GAT TCG AAC ACT GCT GAT AAA $\begin{array}{llllllllllllll}\mathrm{V} & \mathrm{I} & \mathrm{E} & \mathrm{S} & \mathrm{T} & \mathrm{L} & \mathrm{S} & \mathrm{D} & \mathrm{S} & \mathrm{N} & \mathrm{T} & \mathrm{A} & \mathrm{D} & \mathrm{K}\end{array}$ ATT GCT CTA ATA TAC GAG GAT GAg GAA ACA TGC GTC AAG CAC

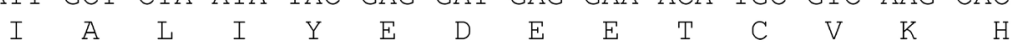
ACG TAC GCT GAA CTG AAC ATC ATC ACC AAT AAA CTT GCG AGG $\begin{array}{llllllllllllll}T & Y & A & E & L & N & I & I & T & N & K & I & A & R\end{array}$ GTT ATC AAG AAT AAA ATA ACA CAA GAA AAC CTC CAA AGA AAC $\begin{array}{lllllllllllllll}\mathrm{V} & \mathrm{I} & \mathrm{K} & \mathrm{N} & \mathrm{K} & \mathrm{I} & \mathrm{T} & \mathrm{Q} & \mathrm{E} & \mathrm{N} & \mathrm{L} & \mathrm{Q} & \mathrm{R} & \mathrm{N}\end{array}$

CTT GAT GGT GAC TAT TTG GTG GCA GTG AAT CTT CTT CCT ACA $\begin{array}{llllllllllllll}\text { L } & D & G & D & Y & \text { L } & \text { V } & \text { A } & \text { V } & \text { N } & \text { L } & \text { L } & \text { P } & \text { T }\end{array}$ GAT CGT TTA GTA ATG GTT CTC CTG GCA ATT TGG AAA GCA GGT $\begin{array}{llllllllllllll}D & R & I & V & M & V & \text { L } & \text { L } & A & I & W & K & A & G\end{array}$ GCG GCA TAC CTT CCA TTG GAC CAT GCT TTT CCA GGT GCA AGA $\begin{array}{llllllllllllll}\text { A } & \text { A } & Y & \text { L } & \text { P } & \text { L } & \text { D } & \text { H } & \text { A } & \text { F } & \text { P } & \text { G } & \text { A } & \text { R }\end{array}$ ATA GAG CAC ATT ATG AGG GAG GCT AAA CCT GCT CTC GTA ATT $\begin{array}{llllllllllllll}I & \mathrm{E} & \mathrm{H} & \mathrm{I} & \mathrm{M} & \mathrm{R} & \mathrm{E} & \mathrm{A} & \mathrm{K} & \mathrm{P} & \mathrm{A} & \mathrm{I} & \mathrm{V} & \mathrm{I}\end{array}$ CAC GAT GAA GAT TCA GAT TTT TAC GTC GAC GCT TTC AAA CTT $\begin{array}{llllllllllllll}\mathrm{H} & \mathrm{D} & \mathrm{E} & \mathrm{D} & \mathrm{S} & \mathrm{D} & \mathrm{F} & \mathrm{Y} & \mathrm{V} & \mathrm{D} & \mathrm{A} & \mathrm{F} & \mathrm{K} & \mathrm{L}\end{array}$ CCA ATT GAA GAA ATG TGG TCG ATG GCA AGT AGg GAA AGT GAA $\begin{array}{llllllllllllll}P & I & E & E & M & W & S & M & A & S & R & E & S & E\end{array}$ TTA GGA TTG AAA AAG AAT GAA CGT CTT AAG CAC CAA AGC GGA $\begin{array}{llllllllllllll}\text { L } & G & \text { L } & \text { K } & \text { K } & \text { N } & \text { E } & \text { R } & \text { L } & \text { K } & \text { H } & \text { O } & \text { S } & \text { G }\end{array}$ GAC CTG GCT ATT GCC TTG TAT ACC TCT GGA AGC ACA GGG GTA $\begin{array}{llllllllllllll}D & \mathrm{~L} & \mathrm{~A} & \mathrm{I} & \mathrm{A} & \mathrm{L} & \mathrm{Y} & \mathrm{T} & \mathrm{S} & \mathrm{G} & \mathrm{S} & \mathrm{T} & \mathrm{G} & \mathrm{V}\end{array}$ CCC AAA GGT GTG AAA CTA ATG CAC AAG GTA ATC TTG AAT CGA $\begin{array}{lllllllllllllll}\mathrm{P} & \mathrm{K} & \mathrm{G} & \mathrm{V} & \mathrm{K} & \mathrm{L} & \mathrm{M} & \mathrm{H} & \mathrm{K} & \mathrm{V} & \mathrm{I} & \mathrm{L} & \mathrm{N} & \mathrm{R}\end{array}$ CTG AAT TGG CAA TTC AAA GCT TTT CCC TAT AGC GAC ACC GAA $\begin{array}{llllllllllllll}\mathrm{L} & \mathrm{N} & \mathrm{W} & \mathrm{Q} & \mathrm{F} & \mathrm{K} & \mathrm{A} & \mathrm{F} & \mathrm{P} & \mathrm{Y} & \mathrm{S} & \mathrm{D} & \mathrm{T} & \mathrm{E}\end{array}$ AAT GTA TGT GTG TTC AAG ACA GCC TTG ACG TTC GTA GAT AGT $\begin{array}{llllllllllllll}\mathrm{N} & \mathrm{V} & \mathrm{C} & \mathrm{V} & \mathrm{F} & \mathrm{K} & \mathrm{T} & \mathrm{A} & \mathrm{L} & \mathrm{T} & \mathrm{F} & \mathrm{V} & \mathrm{D} & \mathrm{S}\end{array}$ GTT TCA GAA ATC TGG GGC CCT CTG ATC AAg AAg TTG GCA CTT $\begin{array}{llllllllllllll}V & S & E & I & W & G & P & \text { L } & \text { I } & \text { K } & \text { K } & \text { I } & \text { A } & \text { L }\end{array}$ CTA GTT ATT CCC AAG GAG GTC ACC AAA GAC CCC GAA CGA CTG $\begin{array}{llllllllllllll}\mathrm{L} & \mathrm{V} & \mathrm{I} & \mathrm{P} & \mathrm{K} & \mathrm{E} & \mathrm{V} & \mathrm{T} & \mathrm{K} & \mathrm{D} & \mathrm{P} & \mathrm{E} & \mathrm{R} & \mathrm{L}\end{array}$ ATA GAA TCC TTA GAA AGA TAT AAg GTT GAG AGA TTA GTT TTA

$\begin{array}{llllllllllllll}I & E & S & L & E & R & Y & K & V & E & R & L & V & L\end{array}$ 
GTG CCC TCC TTA TTG AgA TCG ATt CTG ATG TTt CTA GAA AtC

$\begin{array}{llllllllllllll}V & \mathrm{P} & \mathrm{S} & \mathrm{L} & \mathrm{L} & \mathrm{R} & \mathrm{S} & \mathrm{I} & \mathrm{L} & \mathrm{M} & \mathrm{F} & \mathrm{L} & \mathrm{E} & \mathrm{I}\end{array}$

CAg AAt AAg AAT GgA AtC tTG TCG AAT CTC AAA ACG TGG GtA $\begin{array}{lllllllllllllll}Q & \mathrm{~N} & \mathrm{~K} & \mathrm{~N} & \mathrm{G} & \mathrm{I} & \mathrm{L} & \mathrm{S} & \mathrm{N} & \mathrm{L} & \mathrm{K} & \mathrm{T} & \mathrm{W} & \mathrm{V}\end{array}$

TGC TCT GGA GAA ACA CTC GTG AAA AGT GCA GCA GTA GAT TTC $\begin{array}{lllllllllllllll}C & S & G & E & T & \text { L } & V & K & S & A & A & V & D & F\end{array}$

TAC AAG TAT TTC CCT GAA AAC GAA CAT CGT CTT TGT AAT TTT $\begin{array}{lllllllllllllll}\mathrm{Y} & \mathrm{K} & \mathrm{Y} & \mathrm{F} & \mathrm{P} & \mathrm{E} & \mathrm{N} & \mathrm{E} & \mathrm{H} & \mathrm{R} & \mathrm{L} & \mathrm{C} & \mathrm{N} & \mathrm{F}\end{array}$

TAC GGA AGC ACT GAA ATT ATG GGC GAC GTA ACT TAC TAC GTC $\begin{array}{llllllllllllll}Y & G & S & T & E & I & M & G & D & V & T & Y & Y & V\end{array}$ ATA AAA GGA TTA GAT CAA CTG GCT ACT ATT GAA AAA ATT CCT $\begin{array}{lllllllllllllll}I & K & G & \mathrm{~L} & \mathrm{D} & \mathrm{Q} & \mathrm{L} & \mathrm{A} & \mathrm{T} & \mathrm{I} & \mathrm{E} & \mathrm{K} & \mathrm{I} & \mathrm{P}\end{array}$ ATA GGC GTC CCA GTC GAC AAC ACC ATC ATC TAT CTT CTG GAC $\begin{array}{llllllllllllll}I & G & V & P & V & D & N & \text { T } & \text { I } & \text { I } & \text { Y } & \text { L } & \text { L } & \text { D }\end{array}$ CCG GAG TTC CGC CCT GTA AAA GCA GGA GAA ATT GGT GAA TTA $\begin{array}{llllllllllllll}\mathrm{P} & \mathrm{E} & \mathrm{F} & \mathrm{R} & \mathrm{P} & \mathrm{V} & \mathrm{K} & \mathrm{A} & \mathrm{G} & \mathrm{E} & \mathrm{I} & \mathrm{G} & \mathrm{E} & \mathrm{I}\end{array}$ TAC GTT TCC GGT TTA AAT CTT GCA GCG GGA TAC ATA AAT GGT $\begin{array}{llllllllllllll}Y & V & S & G & L & N & L & A & A & G & Y & I & N & G\end{array}$ AGA GAT CCT GAC AAA TTC CTC GAT AAT CCC TTA GCC AtA GAT $\begin{array}{llllllllllllll}R & D & P & D & K & F & L & D & N & P & \text { L } & A & I & D\end{array}$ CCA ACA TAT GCT AAA ATT TAT AGA ACA GGC GAT TTC GCT AGG $\begin{array}{lllllllllllllll}P & \mathrm{~T} & \mathrm{Y} & \mathrm{A} & \mathrm{K} & \mathrm{I} & \mathrm{Y} & \mathrm{R} & \mathrm{T} & \mathrm{G} & \mathrm{D} & \mathrm{F} & \mathrm{A} & \mathrm{R}\end{array}$

TTG GAG AAA GGA GTT CTC TTA TAC GAA GGA AGA ACC GAT TCA $\begin{array}{lllllllllllllll}\mathrm{L} & \mathrm{E} & \mathrm{K} & \mathrm{G} & \mathrm{V} & \mathrm{L} & \mathrm{L} & \mathrm{Y} & \mathrm{E} & \mathrm{G} & \mathrm{R} & \mathrm{T} & \mathrm{D} & \mathrm{S}\end{array}$ CAG GTA AAA ATT AGG GGA CAT CGT GTA GAT CTG ACG GAG GTA $\begin{array}{lllllllllllllll}2 & V & K & I & R & G & H & R & V & D & \text { L } & \text { T } & \text { E } & \text { V }\end{array}$ GAA AAG GCA GTT TCT TCA ATA GAA GAG ATA GAA AAG GCC GTT

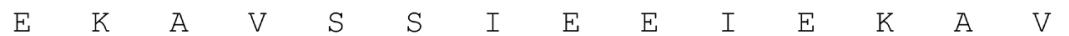
GTC CTC TGC TAT AAA CCT GGT GAA ATG AGT CAG GCA CTT TTA $\begin{array}{llllllllllllll}V & \mathrm{~L} & \mathrm{C} & \mathrm{Y} & \mathrm{K} & \mathrm{P} & \mathrm{G} & \mathrm{E} & \mathrm{M} & \mathrm{S} & \mathrm{Q} & \mathrm{A} & \mathrm{L} & \mathrm{L}\end{array}$ GCT TTC GTA ACA ACC AAA CAA TTA GTA AGC GAA AGT TGG ATT $\begin{array}{llllllllllllll}A & F & V & T & T & K & Q & L & V & S & E & S & W & I\end{array}$ GAA GCT TAT TTG AGA AAA AAA CTA ACT CCA TAC ATG ATT CCA $\begin{array}{llllllllllllll}\mathrm{E} & \mathrm{A} & \mathrm{Y} & \mathrm{L} & \mathrm{R} & \mathrm{K} & \mathrm{K} & \mathrm{L} & \mathrm{T} & \mathrm{P} & \mathrm{Y} & \mathrm{M} & \mathrm{I} & \mathrm{P}\end{array}$ CAA GTG ATT CTT GTA GAA TCC ATA CCG CTC TTG GTA AAC GGA $\begin{array}{llllllllllllll}Q & \mathrm{~V} & \mathrm{I} & \mathrm{L} & \mathrm{V} & \mathrm{E} & \mathrm{S} & \mathrm{I} & \mathrm{P} & \mathrm{L} & \mathrm{L} & \mathrm{V} & \mathrm{N} & \mathrm{G}\end{array}$ AAA ATT GAC CGG CAG AGC TTG CTC AAG ATG TAC GAA AAC ACT $\begin{array}{llllllllllllll}K & \mathrm{I} & \mathrm{D} & \mathrm{R} & \mathrm{Q} & \mathrm{S} & \mathrm{L} & \mathrm{L} & \mathrm{K} & \mathrm{M} & \mathrm{Y} & \mathrm{E} & \mathrm{N} & \mathrm{T}\end{array}$ AAC AAT AAC AAT GAT GAT CAA TAC CAA GTC GAT ATA GAT TAC $\begin{array}{llllllllllllll}\mathrm{N} & \mathrm{N} & \mathrm{N} & \mathrm{N} & \mathrm{D} & \mathrm{D} & \mathrm{Q} & \mathrm{Y} & \mathrm{Q} & \mathrm{V} & \mathrm{D} & \mathrm{I} & \mathrm{D} & \mathrm{Y}\end{array}$ 
ACA GGA GTT CCT CCA AAT CAA ATG GCA GCC GCT AAG ATA CTT

$\begin{array}{llllllllllllll}\mathrm{T} & \mathrm{G} & \mathrm{V} & \mathrm{P} & \mathrm{P} & \mathrm{N} & \mathrm{Q} & \mathrm{M} & \mathrm{A} & \mathrm{A} & \mathrm{A} & \mathrm{K} & \mathrm{I} & \mathrm{L}\end{array}$

TTC GAA ACT GTC GGT GAA GTT CTG AAT AGA GCT GCT AGA GCT

$\begin{array}{llllllllllllll}\mathrm{F} & \mathrm{E} & \mathrm{T} & \mathrm{V} & \mathrm{G} & \mathrm{E} & \mathrm{V} & \mathrm{L} & \mathrm{N} & \mathrm{R} & \mathrm{A} & \mathrm{A} & \mathrm{R} & \mathrm{A}\end{array}$

GCT ATA AAA TTA GAC GCC AAC TTT TAT AGT CTT GGT GGA AAC

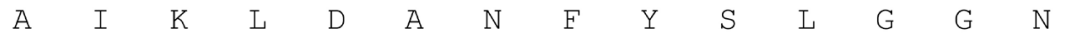

TCT TTG AAT TCT ATT TAC ACC ATT ACC AAG CTT AGC GAA AAA $\begin{array}{lllllllllllllll}\mathrm{S} & \mathrm{L} & \mathrm{N} & \mathrm{S} & \mathrm{I} & \mathrm{Y} & \mathrm{T} & \mathrm{I} & \mathrm{T} & \mathrm{K} & \mathrm{L} & \mathrm{S} & \mathrm{E} & \mathrm{K}\end{array}$

GgG TAC AGA ATt GCT AtA Agt GAC TTC ATA GCA GCt TTG GAT $\begin{array}{llllllllllllll}G & Y & R & I & A & I & S & D & F & I & A & A & L & D\end{array}$

CTT GGA GAA GTT TTA GAg AgG ATG ACA GCT GgG ACC ATG GTC

$\begin{array}{llllllllllllll}\mathrm{L} & \mathrm{G} & \mathrm{E} & \mathrm{V} & \mathrm{L} & \mathrm{E} & \mathrm{R} & \mathrm{M} & \mathrm{T} & \mathrm{A} & \mathrm{G} & \mathrm{T} & \mathrm{M} & \mathrm{V}\end{array}$

AAT ATA CAA CCC CCC CAG TTC ACA GCT AGT CTT TGC AAG TCG $\begin{array}{lllllllllllllll}\mathrm{N} & \mathrm{I} & \mathrm{Q} & \mathrm{P} & \mathrm{P} & \mathrm{Q} & \mathrm{F} & \mathrm{T} & \mathrm{A} & \mathrm{S} & \mathrm{L} & \mathrm{C} & \mathrm{K} & \mathrm{S}\end{array}$

CTC GAC AAA GAA TTA GTC ATA TCG ATA ATA ACA GAG AGT TTC

$\begin{array}{lllllllllllllll}\mathrm{L} & \mathrm{D} & \mathrm{K} & \mathrm{E} & \mathrm{L} & \mathrm{V} & \mathrm{I} & \mathrm{S} & \mathrm{I} & \mathrm{I} & \mathrm{T} & \mathrm{E} & \mathrm{S} & \mathrm{F}\end{array}$

TAC AGA AAA GCG GAT TTG GAA CAG TGG ATT TTA TCG GAA AtA

$\begin{array}{llllllllllllll} & \mathrm{R} & \mathrm{K} & \mathrm{A} & \mathrm{D} & \mathrm{L} & \mathrm{E} & \mathrm{Q} & \mathrm{W} & \mathrm{I} & \mathrm{L} & \mathrm{S} & \mathrm{E} & \mathrm{I}\end{array}$

TCC GAG AAC GAT TAC AAA AAG TAT CTC GAT GAT ATT TGG GAA $\begin{array}{llllllllllllllll}\mathrm{S} & \mathrm{E} & \mathrm{N} & \mathrm{D} & \mathrm{Y} & \mathrm{K} & \mathrm{K} & \mathrm{Y} & \mathrm{L} & \mathrm{D} & \mathrm{D} & \mathrm{I} & \mathrm{W} & \mathrm{E}\end{array}$ CCA tTG GTG AAg AAA GAA TTG AGT TTT ATT GTA AAA AAT GAA $\begin{array}{lllllllllllllllllll}P & \mathrm{~L} & \mathrm{~V} & \mathrm{~K} & \mathrm{~K} & \mathrm{E} & \mathrm{L} & \mathrm{S} & \mathrm{F} & \mathrm{I} & \mathrm{V} & \mathrm{K} & \mathrm{N} & \mathrm{E}\end{array}$

TAT CAG AAG GTA GTA GGG GCA TGT ATC AAC TTC GAT CTT ATG $\begin{array}{llllllllllllll} & \mathrm{Q} & \mathrm{K} & \mathrm{V} & \mathrm{V} & \mathrm{G} & \mathrm{A} & \mathrm{C} & \mathrm{I} & \mathrm{N} & \mathrm{F} & \mathrm{D} & \mathrm{L} & \mathrm{M}\end{array}$

GAC GAA CCA GAA GTA GAG ATA GAT TCT GGA TTG ATT AAG ATA

$\begin{array}{llllllllllllll}D & E & P & E & V & E & I & D & S & G & L & I & K & I\end{array}$

TTC GAA TTT TTA GAC TTT GTG GAA GGA CCA ATC AGG AAA TCC

$\begin{array}{lllllllllllllllll}\mathrm{F} & \mathrm{E} & \mathrm{F} & \mathrm{L} & \mathrm{D} & \mathrm{F} & \mathrm{V} & \mathrm{E} & \mathrm{G} & \mathrm{P} & \mathrm{I} & \mathrm{R} & \mathrm{K} & \mathrm{S}\end{array}$

AGg CTA CCC GCA GAA AAG AAC AAA ACT CTT CAT TGT CAT ATG $\begin{array}{llllllllllllll}R & \mathrm{~L} & \mathrm{P} & \mathrm{A} & \mathrm{E} & \mathrm{K} & \mathrm{N} & \mathrm{K} & \mathrm{T} & \mathrm{L} & \mathrm{H} & \mathrm{C} & \mathrm{H} & \mathrm{M}\end{array}$

ATG GGT ACA CAC AGT TCA TTA ACA TCA AAA GAA AAC ATT CTT $\begin{array}{llllllllllllll}M & G & T & H & S & S & L & T & S & K & E & N & I & L\end{array}$

GTG ATA CAA TTT ATG GAG GAG GAA GTA TAT AAA CTT GCT AAA $\begin{array}{lllllllllllllll}V & I & Q & F & M & E & E & E & V & Y & K & L & A & K\end{array}$

ACT AGA GGA TTC GAG AAg ATA CTC ACA GTT AAT ACT AGT CCT $\begin{array}{llllllllllllll}\mathrm{T} & \mathrm{R} & \mathrm{G} & \mathrm{F} & \mathrm{E} & \mathrm{K} & \mathrm{I} & \mathrm{L} & \mathrm{T} & \mathrm{V} & \mathrm{N} & \mathrm{T} & \mathrm{S} & \mathrm{P}\end{array}$

CTT ACC CAG CAA CTA GGA AGA GAC GTT tTC AAA TAC GAA GTA $\begin{array}{lllllllllllllll}\mathrm{L} & \mathrm{T} & \mathrm{Q} & \mathrm{Q} & \mathrm{L} & \mathrm{G} & \mathrm{R} & \mathrm{D} & \mathrm{V} & \mathrm{F} & \mathrm{K} & \mathrm{Y} & \mathrm{E} & \mathrm{V}\end{array}$

TTA TTG GAT TAT CAA GTG AAT AAA TAT GTA GCA CCC GAC AAC $\begin{array}{lllllllllllllll}\mathrm{L} & \mathrm{L} & \mathrm{D} & \mathrm{Y} & \mathrm{Q} & \mathrm{V} & \mathrm{N} & \mathrm{K} & \mathrm{Y} & \mathrm{V} & \mathrm{A} & \mathrm{P} & \mathrm{D} & \mathrm{N}\end{array}$ 
Figure S1. Nucleotide sequence and translated amino acid sequence for predicted ebony gene transcript from transcriptomes of two individual adult C. maculata specimens. Illumina sequences were assembled individually and combined, and all assemblies resulted in the same predicted sequence. Lower case letters indicate untranslated sequence.

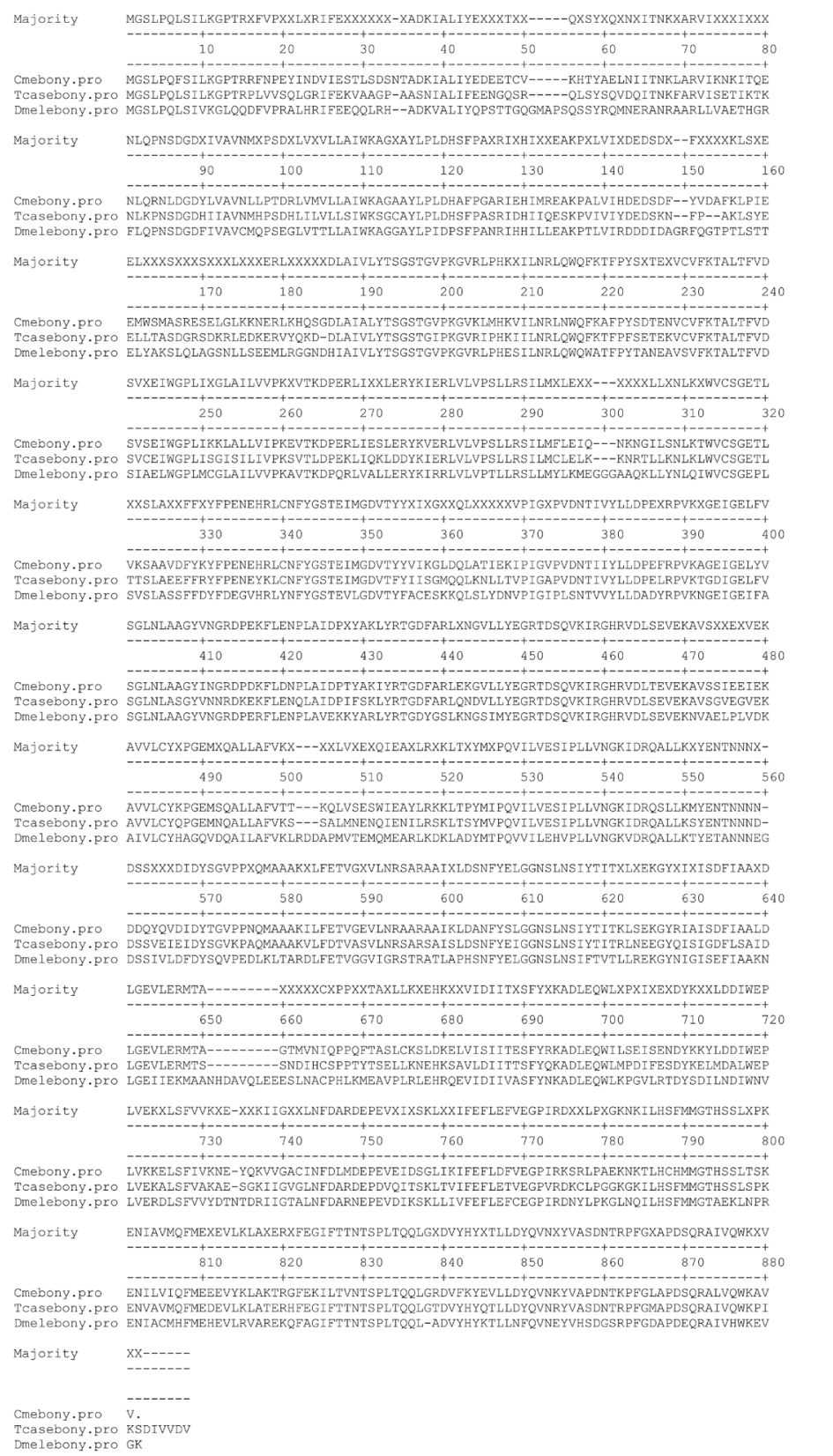

Figure S2. ClustalW alignment (Gonnet method) of predicted translated ebony sequence with predicted sequence from Tribolium castaneum genome project, and validated sequence from Drosophila melanogaster. 


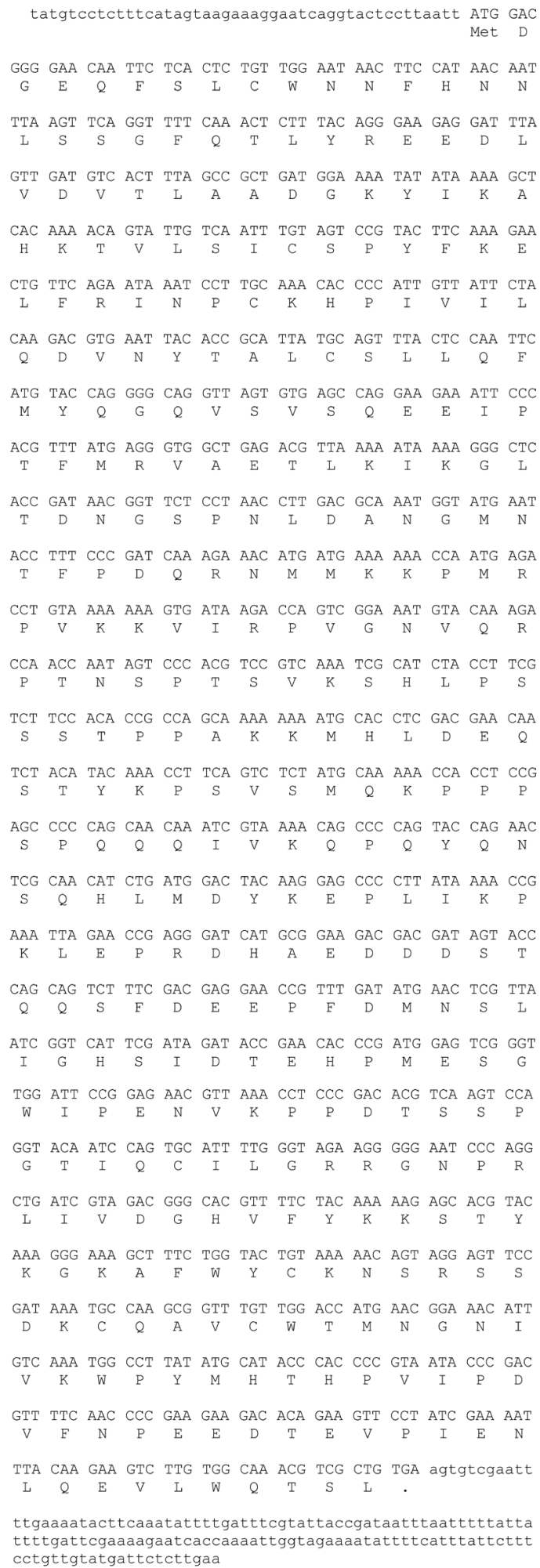

Figure S3. Nucleotide sequence and translated amino acid sequence for predicted bric-a-brac gene transcript from transcriptomes of two individual adult $C$. maculata specimens. Illumina sequences were assembled individually and combined, and all assemblies resulted in the same predicted sequence. Lower case letters indicate untranslated sequence. 

CQHPIVIMRDVNWSDLKAIVEFMYRGEINVSQDQIGPLLRIAEMLKVRGLADVTHMEAATAAAAAASSERMPSSPKESTS

XSXXEXNXXXXXXXXXXXXFXDQRXXMKXPXRPVKKVIXPXXXXXX---------PXXSPXXXXPHPPS--SSXXPAKRMHL

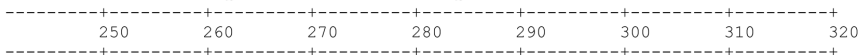
IDANGMN------TFPDQRNMMKKPMRPVKKVIRPVGNVQR------PTNSPTSVKSHLPS--SSTPPAKKMHI TSRTEHDREREAEELLAFMQPEKKLRTS DWDPAELRLSPLERQQGRNVRKRRWPSADTI FNPPAPPSPLSSLIAAERMEL EEXXXXXXX------XXXXKPPXSXXXXXXXXXXXXQXXXXHXXDXPEPLXKRPKXEPRDXXEXXXXSTQQXFXEX-------PLD

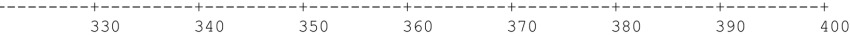
DEQSTYKPS----VSMQKPPPSPQQQIVKQPQYQNSQHLMDYKEPLIKPKLEPRDHAEDDDSTQQSFDEE-----PFD

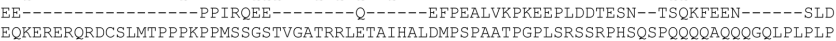
LXXXXXXSIXXXXSXXXGXIXXXXKPXDXS-

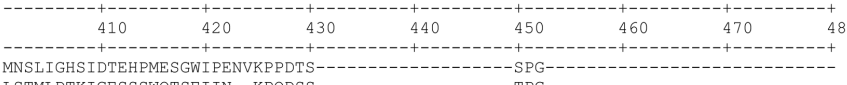
HPHHASAPHPSOTAGSAHHPASAGDSRFPLGPAAAMAAARELSGLGPGPSAEPRLPPPPPHHHGGGGVGGGGVGGG

--_-_-_-_-_QCILGRRGNPRL IVDGHVFYKKS--------XYKGKAFWYCKNSRSXXKCQAVCWT

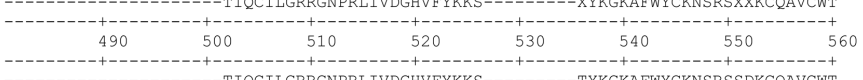
GAGGGSGGGSSIADD TcasbricabracProtein Dmelbricabrac.pro MNGNIVKWPYMHTHPVIPDVFNP-----XEDTEVPIXNLQEVLWQTSXX--

\begin{tabular}{|c|c|c|c|c|c|c|}
\hline 570 & 580 & 590 & 600 & 610 & 620 & 630 \\
\hline
\end{tabular}
MNGNIVKWPYMHTHPVIPDVFNP-----EEDTEVPIENLQEVLWQTSL, ERGPLKSWRPETMAEAIFSVLKEGISLSQAARKYDI PYPTFVLYYANRVHNML,GPS IDGGPDLRPKGRGRPQRILLGIWPD

TcasbricabracProt

$\begin{aligned}- & \\ -1 & \end{aligned}$

Cmacbricabrac.pro TcasbricabracProtein.pro Dmelbricabrac.pro EHIKGVIKTVVFRDTKDIKDESLAAHMPPYGRHSDLPLSY PGASGALAGAPSSMACPNGSGPQTGVGVAGEQHMSQETAA

Majority

-

Cmacbricabrac.pro TcasbricabracProtein.pro Dmelbricabrac.pro AVAAVAHNIRQQMQMAAVPPGLFNLPPHPGVGGGVGNVPGAAGGRASISPALSSGSGPRHAPSPCGPAGLLPNLPPSMAV

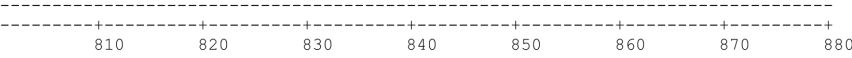

Cmacbricabrac.pro TcasbricabracProtein pro Dmelbricabrac.pro

$$
\text { AL }
$$

ALHHQQQQQAAHHHMQQLHLQQQQAHLHHHQQQQQQQQQQHHQGGHQVAHKSGFGASSSSSASSSSMGQHHAPKAKSSPL

Majority

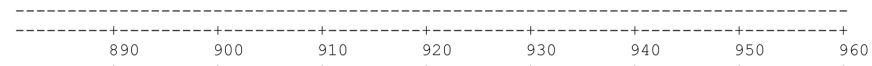

Cmacbricabrac.pro ricabrac.pro

RSETPRLHSPLGDLGLDMASYKREFSPSRLFAEDLAELVGASVSSSSSSAAATAPPERSAGAASAATGADAPSSSSSGG

Majority

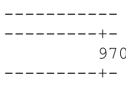

Cmacbricabrac.pro

tein.pr

IKVEPITTTSE

Figure S4. ClustalW alignment (Gonnet method) of predicted translated bric-a-brac sequence with predicted sequence from Tribolium castaneum genome project, and validated sequence from Drosophila melanogaster. 